\title{
USE OF NON-METALLIC E-WASTE AS A COARSE AGGREGATE IN A CONCRETE
}

\author{
Pravin A. Manatkar', Ganesh P.Deshmukh ${ }^{2}$ \\ ${ }^{I}$ Student of M.E (Structural Engineering), PLITMS College Buldana, Maharashtra, India \\ ${ }^{2}$ Associate Professor, Civil Engineering Department, PLITMS College Buldana, Maharashtra, India
}

\begin{abstract}
Generation of e-waste is a very serious issue in world. In year 2014 produce near about 650000MT of e-waste in India that includes all waste electronics and electrical equipment( TVs, computers, sound systems, refrigerators etc). This waste not dispose properly finally they affect environment and human health and also create storage problem. This waste is to be utilizing as coarse aggregate in concrete. It is helpful to avoid pollution and provide replacing material to coarse aggregate. In this paper shows analysis of compressive strength of M20 and M25 grade of concrete by replacing coarse aggregate by adding non metallic $e$-waste in $0 \%$ to $20 \%$ and it is observed that some percent non metallic e-waste can be use as a coarse aggregate in concrete.
\end{abstract}

Keywords: Compressive strength, E-waste, Pollution.

\section{INTRODUCTION}

E-waste is nothing but discarded electronics and electrical equipment.80 to $85 \%$ of various electronic products discarded in landfills or incinerators which can involve or release certain toxics gases into air, may affect human health and environment. The extreme amount of lead in electronics alone causes damage in the central and peripheral nervous system, the blood and kidneys of human being. Only $12.5 \%$ of e-waste is currently recycled also Storage of waste is a big problem in India. As per Rajah Sabah analysis 2011 India is topmost country to produce ewaste in yearly. So to avoid pollution and protect environment there is a need to utilize the waste in various purpose. Best way to utilized in concrete as a coarse aggregate.

E - waste was crushed in various sizes and sieve through $4.75 \mathrm{~mm}, 10 \mathrm{~mm}$, and $20 \mathrm{~mm}$. Then various tests were carried out on it i.e. crushing value, abrasion value, impact value and it was positive. Finally it can use to replace coarse aggregate in concrete in various percentage i.e. $5 \%, 10 \%$, $15 \%, 20 \%, 25 \%$.Marked M20 and M25 grade of concrete block of size $150 \mathrm{mmX} 150 \mathrm{mmX} 150 \mathrm{~mm}$ each of 2 block for 7days,14days,28days test. Test is carried out on compressive testing machine having loading capacity 2000KN

\section{MATERIAL}

\subsection{Cement}

As per IS 1489- 1991 for making concrete cube 43 grade ordinary Portland cement was used. Various tests were conducted on this cement their result shown in table 1.Cement purchased from near store. It is in good condition and free from lumps.
Table 1: Properties of Cement

\begin{tabular}{|l|l|l|}
\hline $\begin{array}{l}\text { Properties of } \\
\text { Cement }\end{array}$ & Test Result & $\begin{array}{l}\text { As per IS 1489- } \\
\text { 1991 } \\
\text { Requirement }\end{array}$ \\
\hline $\begin{array}{l}\text { Standard } \\
\text { consistency }\end{array}$ & 29.1 & - \\
\hline $\begin{array}{l}\text { Initial setting } \\
\text { time }\end{array}$ & 41 minutes & Max. 30 minutes \\
\hline $\begin{array}{l}\text { Final setting } \\
\text { time }\end{array}$ & 360 minutes & Max. 600 minutes \\
\hline $\begin{array}{l}\text { Compressive } \\
\text { strength after } \\
\text { 3days in N/mm }\end{array}$ & 29.5 & $23 \mathrm{~N} / \mathrm{mm}^{2}$ \\
\hline $\begin{array}{l}\text { Compressive } \\
\text { strength after } \\
\text { 7days in N/mm }\end{array}$ & 37.2 & $33 \mathrm{~N} / \mathrm{mm}^{2}$ \\
\hline $\begin{array}{l}\text { Compressive } \\
\text { strength after } \\
\text { 28days in } \\
\text { N/mm }{ }^{2}\end{array}$ & 44.3 & $43 \mathrm{~N} / \mathrm{mm}^{2}$ \\
\hline
\end{tabular}

\subsection{Fine Aggregate}

Natural occurring river sand was used in casting of cube. Various properties are determine as per IS 2386(Part-I) .The result are shown below table 2 .

Table 2: Properties of fine Aggregate

\begin{tabular}{|l|l|}
\hline Properties & Test Result \\
\hline Fineness Modulus & 2.5 \\
\hline Specific Gravity & 2.68 \\
\hline Bulking & $2 \%$ \\
\hline Free Moisture Content & $0.16 \%$ \\
\hline Silt Content & $0.8 \%$ \\
\hline
\end{tabular}




\subsection{Coarse Aggregate}

Coarse aggregate was collected from locally available granite crust stone having maximum size $20 \mathrm{~mm}$.verious test were conducted on this aggregate as per IS 2386-1963 (Part-IV) result are shown below table 3.

Table 3: Properties of coarse Aggregate

\begin{tabular}{|l|l|}
\hline Properties & Test Result \\
\hline Fineness Modulus & 3.2 \\
\hline Specific Gravity & 2.98 \\
\hline Water Absorption & $0.6 \%$ \\
\hline Free Moisture Content & $0.12 \%$ \\
\hline $\begin{array}{l}\text { Aggregate Abrasion } \\
\text { Value }\end{array}$ & $12 \%$ \\
\hline Aggregate Impact Value & $16 \%$ \\
\hline $\begin{array}{l}\text { Aggregate Crushing } \\
\text { Value }\end{array}$ & $21 \%$ \\
\hline
\end{tabular}

\subsection{Water}

Impurities free, clean portable water are use for casting of cube. Also curing was done in curing tank as per IS 4562000

\subsection{Non-metallic E-waste}

Non-metallic e-waste was collected from local body which was discarded in scrap. That can be crushed in various sizes $4.75 \mathrm{~mm}, 10 \mathrm{~mm}, 20 \mathrm{~mm}$. various test were conducted on it as per IS 2386-1963 (Part-IV) result is shown below table 4.

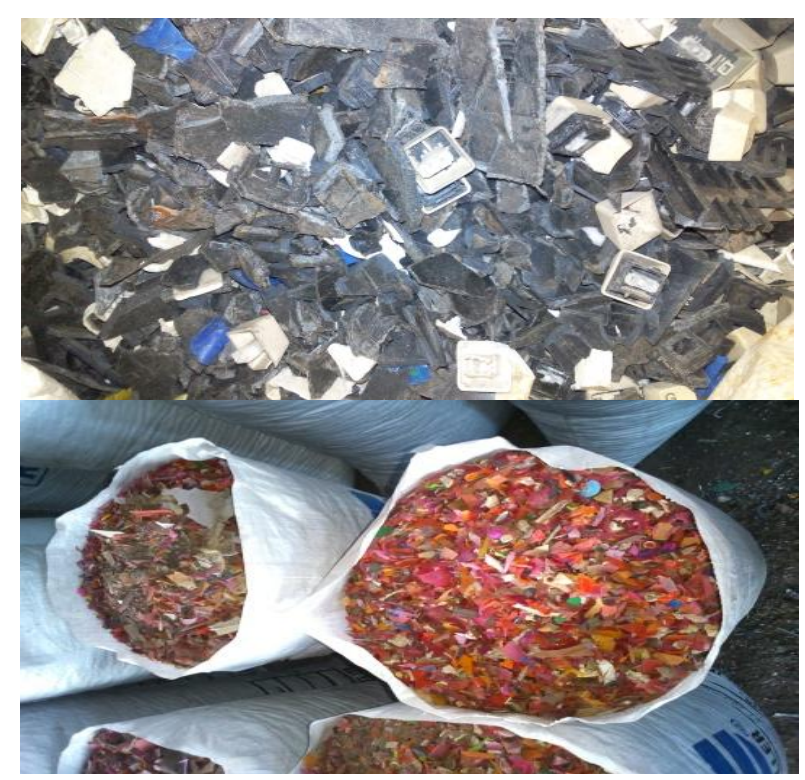

Fig-1: Crushed Non Metallic E-Waste

Table 4: Properties of E-waste

\begin{tabular}{|l|l|}
\hline Properties & Test Result \\
\hline Specific Gravity & 1.2 \\
\hline Water Absorption & $0.1 \%$ \\
\hline Shape & Angular \\
\hline Color & Red ,White and Dark \\
\hline Aggregate Abrasion & $0.6 \%$ \\
\hline
\end{tabular}

\begin{tabular}{|l|l|}
\hline Value & \\
\hline Aggregate Impact Value & $4 \%$ \\
\hline $\begin{array}{l}\text { Aggregate Crushing } \\
\text { Value }\end{array}$ & $2.8 \%$ \\
\hline
\end{tabular}

\section{PROCEDURE}

\subsection{Batching}

Batching was done method of weight batching by using weighing balance having accuracy $0.001 \mathrm{gm}$.

\subsection{Mixing}

Mixing of concrete was done by manually according to the grade of M20 and M25 with water cement ratio 0.50 and 0.40 respectively. Percentage of e-waste added in the concrete as a replacement of coarse aggregate as shown in table 5 .

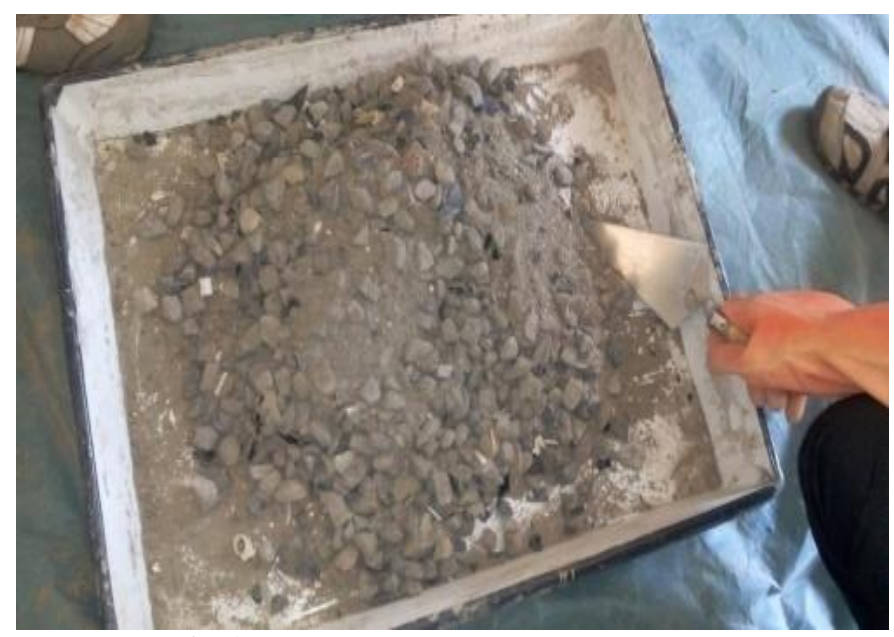

Fig-2: Mixing of e- waste in concrete

\subsection{Casting of cube}

As per requirement for testing each of 2 blocks for 7days, 14days, 28days test for each grade with different percentage.

Table 5: Details of Cube Casting

\begin{tabular}{|l|l|l|l|l|l|}
\hline $\begin{array}{l}\text { \% of e- } \\
\text { waste }\end{array}$ & $\mathbf{0 \%}$ & $\mathbf{5 \%}$ & $\mathbf{1 0 \%}$ & $\mathbf{1 5 \%}$ & $\mathbf{2 0 \%}$ \\
\hline \multirow{2}{*}{$\begin{array}{l}\text { M0 } \\
\text { block }\end{array}$} & 2 & 2 & 2 & 2 & 2 \\
\cline { 2 - 6 } & 2 & 2 & 2 & 2 & 2 \\
\hline \multirow{2}{*}{$\begin{array}{l}\text { M25 } \\
\text { block }\end{array}$} & 2 & 2 & 2 & 2 & 2 \\
\cline { 2 - 6 } & 2 & 2 & 2 & 2 & 2 \\
\cline { 2 - 6 } & 2 & 2 & 2 & 2 & 2 \\
\hline
\end{tabular}

TOTAL $=60$ BLOCKS 


\section{TESTING ON CONCTERE}

\subsection{Workability of Fresh Concrete}

For calculating of workability of fresh concrete slump cone test was used result are shown below table 6 .

Table 6: Result of slump cone test

\begin{tabular}{|l|l|l|}
\hline $\begin{array}{l}\text { Grade of } \\
\text { Concrete }\end{array}$ & $\begin{array}{l}\text { Slump in } \\
\text { mm }\end{array}$ & Workability \\
\hline M20 & 139 & High \\
\hline M25 & 122 & High \\
\hline
\end{tabular}

\subsection{Compressive Strength Test}

Compressive strength test was conducted to calculate compressive strength developed in concrete containing ewaste at the age of $7,14,21$ days respectively. Square mould having size $150 \mathrm{X} 150 \mathrm{X} 150 \mathrm{~mm}$ casted for testing. Tests was done on compressive testing machine (CTM) having loading capacity $2000 \mathrm{KN}$. Result is shown in below table7.

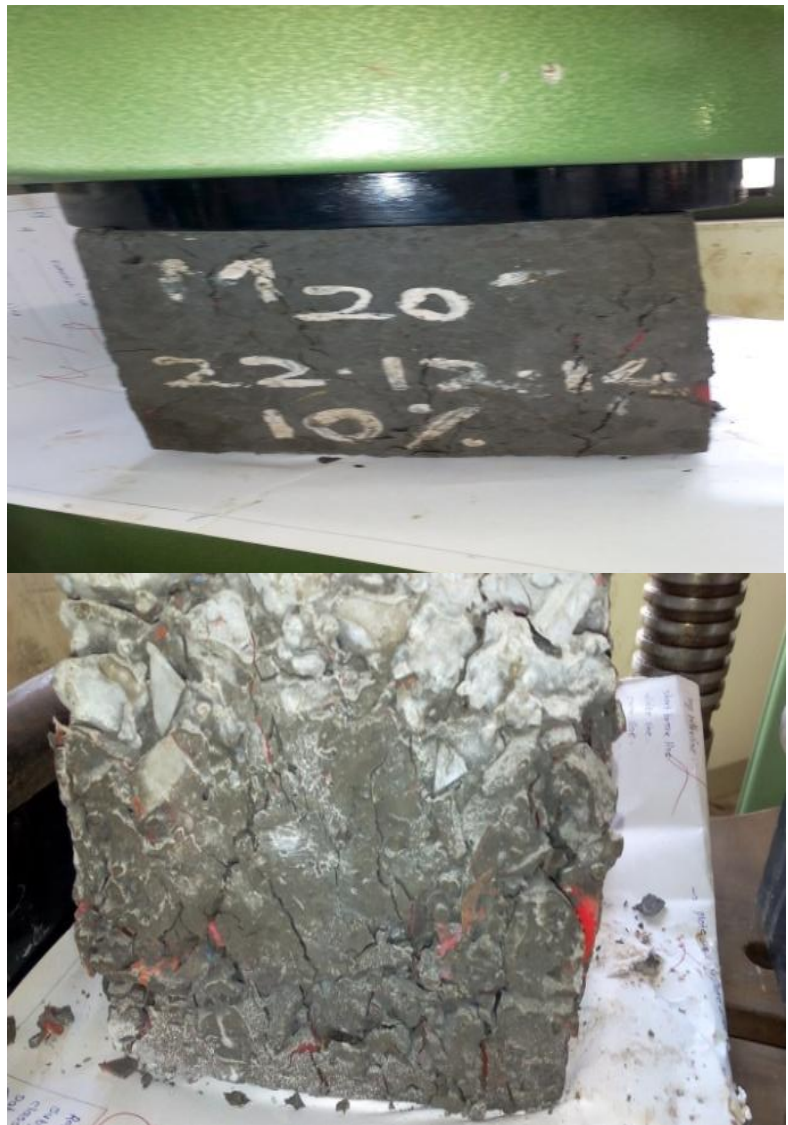

Fig-3: E-Waste block before testing and after testing

For M20 grade

Table 7: Compressive strength test results in N/mm ${ }^{2}$

\begin{tabular}{|l|l|l|l|l|l|}
\hline $\begin{array}{l}\text { Mix proportion of e- } \\
\text { waste }\end{array}$ & $\mathbf{0 \%}$ & $\mathbf{5 \%}$ & $\mathbf{1 0} \%$ & $\mathbf{1 5 \%}$ & $\mathbf{2 0} \%$ \\
\hline 7 Days & 13.12 & 12.96 & 10.22 & 9.52 & 8.00 \\
\hline 14 Days & 18.33 & 18.00 & 16.65 & 12.86 & 11.16 \\
\hline 28 Days & 20.11 & 19.85 & 18.34 & 15.76 & 12.50 \\
\hline
\end{tabular}

For M25 grad

\begin{tabular}{|l|l|l|l|l|l|}
\hline $\begin{array}{l}\text { Mix proportion of e- } \\
\text { waste }\end{array}$ & $0 \%$ & $5 \%$ & $10 \%$ & $15 \%$ & $20 \%$ \\
\hline 7 Days & 16.96 & 16.11 & 13.88 & 11.54 & 10.24 \\
\hline 14 Days & 22.10 & 21.00 & 19.86 & 15.22 & 14.08 \\
\hline 28 Days & 24.98 & 23.26 & 21.73 & 17.78 & 15.22 \\
\hline
\end{tabular}

\section{DISCUSSION}

An analysis made on strength characteristic by conducting test on non-metallic e-waste concrete. The 3days ,7days and 28days compressive strength result of M20 and M25 grade concrete shown in table 7 and analysis by graphically shown in chart land chart 2 .It is observed that compressive strength decrease with increasing e- waste percentage for both grade. Up to $5 \%$, it is nearly same to normal concrete but after $15 \%$, it reduces maximally. Strength reduce because of bonding of e-waste reduces. Volume of e-waste increase then bonding problem occurred in concrete that affect the on strength of concrete 

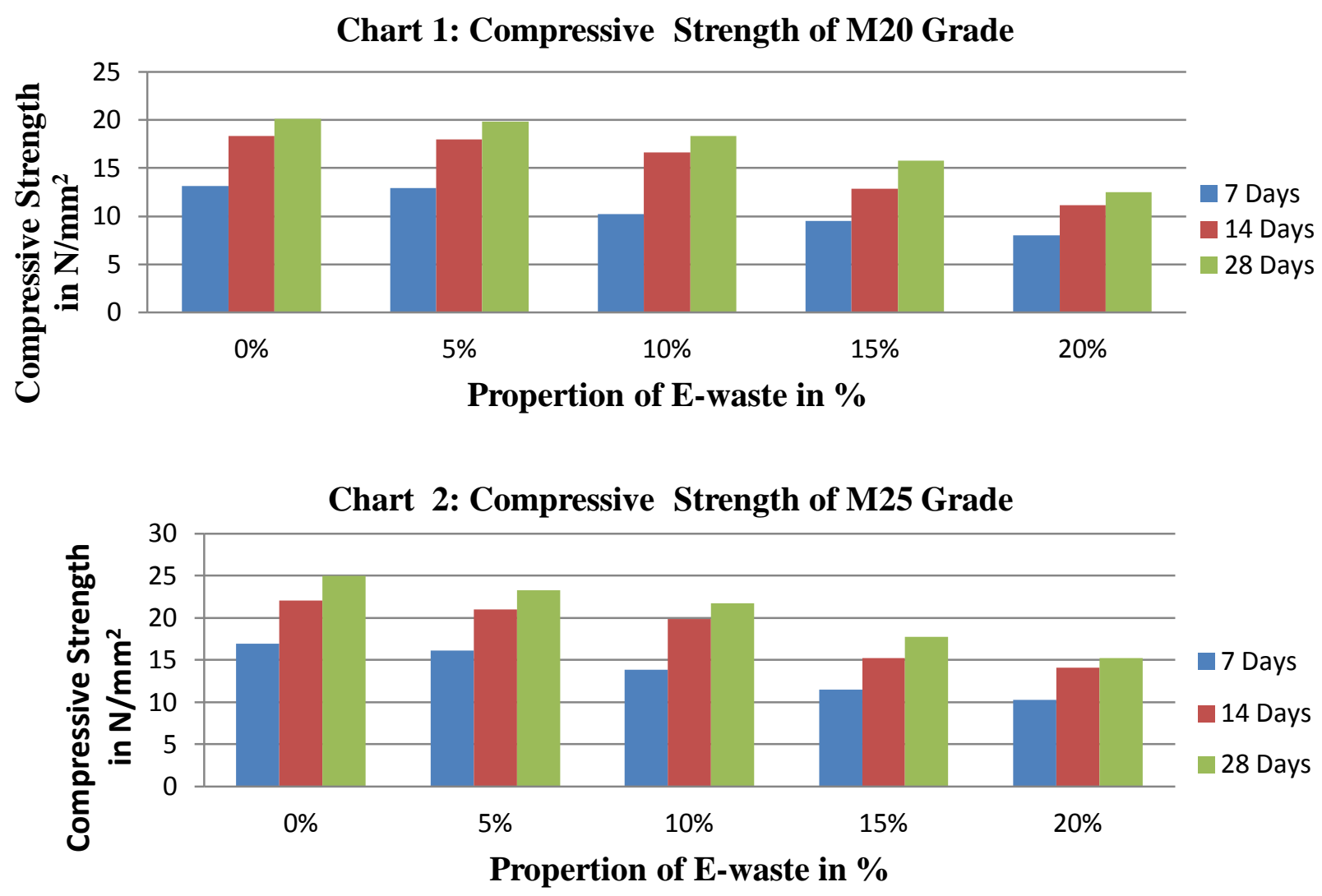

Chart 3: Variation of Compressive Strength aftrer 28 Days

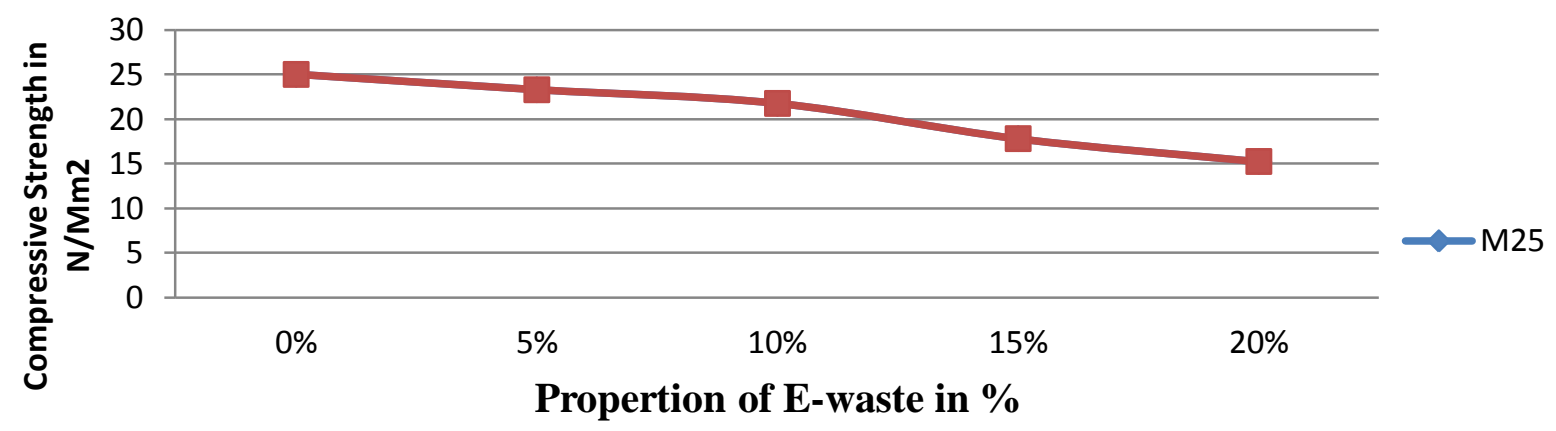

Chart 4: Variation of Compressive Strength aftrer 28 Days

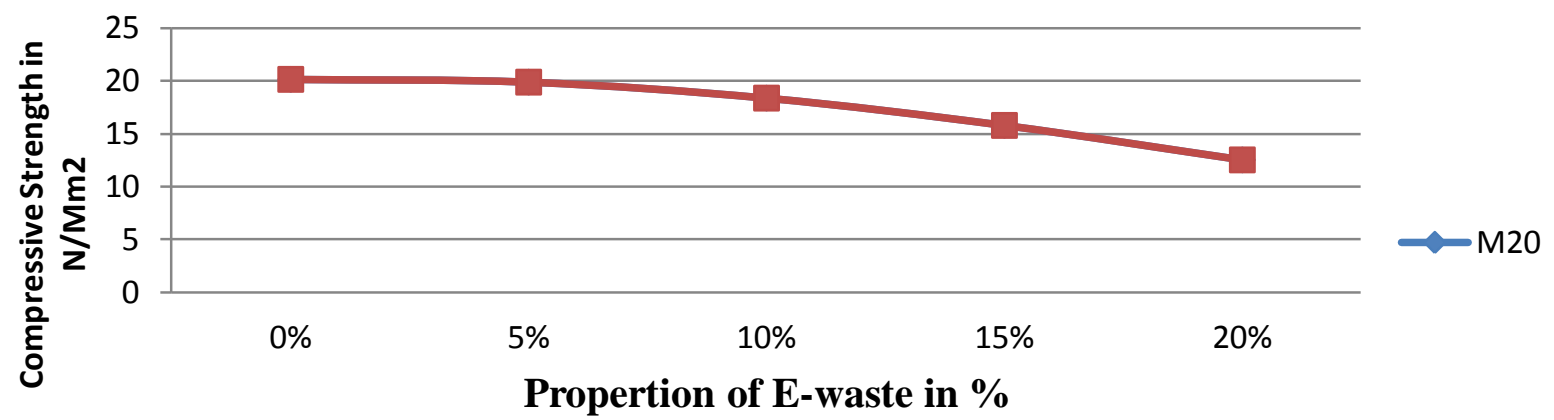




\section{CONCLUSION}

Form experimental analysis it is to be observe that e-waste can be use up to some extent in concrete as coarse aggregate. Following points, give idea about it.

- It is identified that e-waste can dispose in concrete as a coarse aggregate.

- $\quad$ Volume E-waste on earth reduces, when it use in concrete.

- Up to 5-6\% replacement of e-waste is suitable to use up to $(\mathrm{G}+2)$ building construction, road construction.

- Up to $10 \%$ replacement of e-waste is use in construction where low strength required such as garden wall construction etc.

- More than $10 \%$ is not considerably useful for construction field because of strength decreases.

- It was observe that e-waste increase 5\% strength decrease $15 \%$.shown in chart $3 \& 4$

- $\quad$ E-waste concrete block having flexibility it directly not fail during test firstly it compress up to $1 \mathrm{~cm}$ then break. It is very important at the time of earthquake it provides some time for clearance in structure.

- Solid waste management of e-waste done, when it use in concrete.

\section{REFERENCES}

[1] Secung Bum Park, Bong Chun Lee,"Studies on expansion properties in mortar containing waste glass \& fibering. Cement and Concrete Research, vol 34 (2004) pp 1145115

[2] Lakshmi.R, Nagan.S "Studies onconcrete containing e plastic waste" International Journal Of Environmental Sciences Volume 1, No 3,2010

[3] R.Lakshmi, S. Nagan, "Utilization of waste E plastic particles in cementitious mixtures" Journal of StructuralEngineering,Vol.38, No. 1, April - May 2011, pp. 26-35

\section{BIOGRAPHIES}

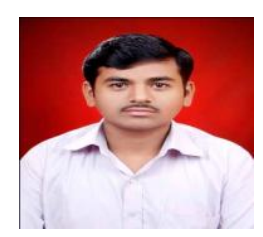

Name:- Pravin Arun Manatkar, Education:- B.E. Civil, M.E. (Structures) Pursuing, Area of Interest :- Structure Contact no.:- 7720909977

Email :-pravinmanatkar@rediffmail.com Address:- At -Hivragadling Post Waghala Tal Shindkhed Raja Dist Buldana State Maharashtra India 443202

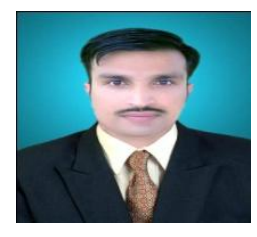

Name:- Ganesh P. Deshmukh, Education: - B.E. Civil, M.E. (Structures),AIME,LMISTE., Area of Interest :- Structure, Contact no.:9730822232

Email :-ganesh_structure@yahoo.co.in Address :- Suyog Building,Ganesh Nagar,Malkapur Road Buldana Dist Buldana State Maharashtra India 443001 